\title{
THE RELATIONSHIP OF DEHYDRATION AND OVERHYDRATION OF THE BLOOD PLASMA TO COLLAPSE IN THE MANAGEMENT OF ARTIFICIAL FEVER THERAPY ${ }^{1}$
}

\author{
BY HERBERT R. BROWN, JR., WILLIAM F. CLARK, NATHANIEL JONES, \\ JOHANNA WALTHER, AND STAFFORD L. WARREN \\ (From the Departments of Medicine and Radiology of the University of Rochester School of \\ Medicine and Dentistry, and the Strong Memorial Hospital, Rochester, New York)
}

(Received for publication April 8, 1942)

The most common serious reaction encountered in the conduct of artificially produced fever therapy is a state of collapse which may appear at any time during the treatment. In 1100 treatments given in our clinic between 1930 and 1937, there was a 1 per cent mortality, and many other serious collapse reactions which were in some way concerned with the water and salt excretion and intake during the treatment. Some of the patients in the early period lost from 3 to $5 \mathrm{kgm}$. in body weight during short treatments of 5 hours, while others lost little or no weight during prolonged treatments ( 10 to 27 hours) at $41.5^{\circ} \mathrm{C}$. Later in this period, when the water intake was better adjusted and sodium chloride administration was included during treatment, the loss in weight was reduced, and the collapse state was less often encountered. Yet it still occurred at odd times in the year and in a curious sequence of cases. It bore no relation to the disease for which the patient was being treated nor to the length of treatment administered, and often occurred in what ordinarily would be termed a "perfectly healthy young adult."

This collapse state has many of the "ear marks" of what is termed surgical or traumatic shock in that there is an absence of sweating and urine, pallor, cold extremities even with rectal temperatures of $41.5^{\circ} \mathrm{C}$. or higher, fall in blood pressure and venous pressure, retardation of the skin capillary response to digital pressure, cyanosis, and coma. Fatal outcome may be precipitated by a maniacal state before the coma ensues. Caffeine and adrenalin are ineffective, and oxygen-carbon dioxide mixtures are only of temporary benefit. In the early stages, vomiting prevents the ingestion of water, although concentrated 2 to 25 per

1 Assisted by grants in aid from the United States Public Health Service and the Rockefeller Foundation. cent saline is occasionally tolerated and may resuscitate the patient. One or more liters of physiological saline injected intramuscularly are usually promptly effective if the collapse state is not too far advanced to prevent its absorption. In such a case, an intravenous injection of this volume must be given and injected slowly. Any intravenous technique for therapeutic administration or chemical data is a difficult maneuver when the information is most desired because the veins are usually collapsed or constricted in the collapse state. Furthermore, any manipulation excites the patient, with a resulting rise in temperature which further increases the precariousness of his situation. This hypersensitivity of the patient has prevented to a great extent any extensive study of his metabolic state. Thus, most data have to be obtained in almost a hit or miss fashion, as opportunity offers.

Alterations of the red blood cell count, hemoglobin (1 to 4 ), and hematocrit, while indicative of hemoconcentration, do not change significantly (greater than 10 per cent) until dehydration is well advanced. Other factors may influence these values, thus rendering them of little aid in the control of fever therapy cases $(2,5$ to 9$)$. Determination of the circulating blood volume (10) or the extravascular water volume (11) during a routine treatment is not a simple procedure and cannot be repeated at will.

The work of Gibson and co-workers $(12,13)$ has shown that a definite decrease of approximately 15 per cent in the circulating blood volume occurs during the induction of artificial fever when sweating is at its maximum. This volume may be decreased still further with resultant hemoconcentration if the water and electrolyte balance is not restored as treatment progresses $(1,14$ to 21). 
From this brief summary, it can be seen that the uniformly safe performance of prolonged artificial fever at high temperatures has definite possibilities if some simple test can be found to indicate which patients are bordering on a precarious state, and likewise to indicate when the proper readjustments to the differing requirements of each patient have to be made. Also, it should be possible to so design the treatment procedure that all of the adjustments of fluid and electrolyte balance can be made by ingestion rather than by injection.

Data accumulated between 1935 and 1939 from 50 cases (Table I), with and without reactions, indicate that while the plasma chloride values did not change much ( 1 to 10 per cent), the values were as apt to rise as they were to fall during the time of the reaction. Furthermore, there was no direct correlation between the chloride values and the change, if any, in the total serum protein. Significant, however, was a striking and constant diminution in the chloride content of the urine. This was first evident in the urine passed during the treatment, for the last urine passed before a collapse state ensued contained little and occasionally no demonstrable chloride. Furthermore, the total urine output for the day or two after treatment was always low in chloride content. Not infrequently, the first 24 -hour volume ( 500 to $2500 \mathrm{cc}$.) might yield only $1 / 4$ to $1 / 2$ gram of chloride, and several days might pass before this rose to 5 or 10 grams for the 24-hour period. The blood chloride was frequently 10 to 30 per cent below normal for a day or so after treatment when collapse had occurred. During this short interval, the patient also regained most of the weight lost during treatment unless vomiting complicated the picture. If 15 grams of sodium chlo-

TABLE I

Characteristic exchanges during treatment at $41.5^{\circ} \mathrm{C}$. before the water and sodium chloride intake was properly adjusted (1935-1938)

Samples were taken just before treatment and at the end of treatment while the patient was still at a temperature of $41.5^{\circ} \mathrm{C}$. These were all patients in excellent physical condition.

\begin{tabular}{|c|c|c|c|c|c|c|c|c|c|c|}
\hline \multirow{2}{*}{ Patients } & \multirow{2}{*}{$\begin{array}{c}\text { At } \\
41.5^{\circ} \\
\text { C. }\end{array}$} & \multicolumn{2}{|c|}{$\begin{array}{c}\text { Total serum } \\
\text { proteins }\end{array}$} & \multicolumn{2}{|c|}{$\begin{array}{l}\text { Blood } \\
\text { chlorides }\end{array}$} & \multirow{2}{*}{$\begin{array}{l}\text { Fluid } \\
\text { intake }\end{array}$} & \multirow{2}{*}{$\begin{array}{l}\text { Urine } \\
\text { during } \\
\text { treat- } \\
\text { ment }\end{array}$} & \multirow{2}{*}{$\begin{array}{c}\mathrm{NaCl} \\
\text { intake }\end{array}$} & \multirow{2}{*}{$\begin{array}{l}\text { Urine } \\
\mathrm{NaCl}\end{array}$} & \multirow{2}{*}{ Reaction } \\
\hline & & Start & End & Start & End & & & & & \\
\hline \multirow[b]{2}{*}{ Mil } & hours & \multicolumn{2}{|c|}{ grams per $100 \mathrm{cc}$. } & \multicolumn{2}{|c|}{ m.eq. per $L$. } & $c c$. & u. & grams & grams & \multirow{5}{*}{$\begin{array}{l}\text { Severe collapse; stopped treatment. } \\
\text { 3rd hour, TP=8.5; } 5 \text { grams of } \mathrm{NaCl} \text { p.o. } \\
\text { stopped collapse. } \\
\text { None. } \\
\text { None. } \\
\text { Collapse; treatment stopped. } \\
\text { No sweating at end of treatment. Otherwise } \\
\text { uneventful. }\end{array}$} \\
\hline & $\begin{array}{r}3 \\
15\end{array}$ & $\begin{array}{l}6.9 \\
6.4\end{array}$ & $\begin{array}{l}8.5 \\
6.9\end{array}$ & $\begin{array}{l}102 \\
102\end{array}$ & $\begin{array}{l}101 \\
111\end{array}$ & $\begin{array}{l}1800 \\
3600\end{array}$ & $\begin{array}{l}60 \\
40\end{array}$ & $\begin{array}{r}0.0 \\
17.5\end{array}$ & $\begin{array}{l}0.0 \\
0.3\end{array}$ & \\
\hline $\begin{array}{l}\text { Fel } \\
\text { Wei }\end{array}$ & $\begin{array}{l}13 \\
16\end{array}$ & $\begin{array}{l}6.7 \\
6.2\end{array}$ & $\begin{array}{l}6.3 \\
6.7\end{array}$ & $\begin{array}{r}93 \\
103\end{array}$ & $\begin{array}{r}104 \\
95\end{array}$ & $\begin{array}{l}4000 \\
3200\end{array}$ & $\begin{array}{l}355 \\
130\end{array}$ & $\begin{array}{l}7.5 \\
0.0\end{array}$ & $\begin{array}{l}1.4 \\
0.3\end{array}$ & \\
\hline Du & 11 & 6.3 & 7.4 & 98 & 98 & 2700 & 0 & 0.0 & 0.0 & \\
\hline & & & & & 99 & 22 & & 0.0 & & \\
\hline $\begin{array}{l}\text { Hut } \\
\text { McB }\end{array}$ & $\begin{array}{l}11 \\
13\end{array}$ & $\begin{array}{l}7.1 \\
7.4\end{array}$ & $\begin{array}{l}7.2 \\
7.2\end{array}$ & $\begin{array}{l}92 \\
97\end{array}$ & $\begin{array}{r}109 \\
98\end{array}$ & $\begin{array}{l}2400 \\
3800\end{array}$ & $\begin{array}{r}228 \\
40\end{array}$ & $\begin{array}{r}20.0 \\
5.0\end{array}$ & $\begin{array}{l}0.4 \\
0.1\end{array}$ & $\begin{array}{l}\text { Vomiting, dry skin. Otherwise uneventful. } \\
\text { Restless; dry skin. Otherwise no reaction. }\end{array}$ \\
\hline Dir & 18 & 5.9 & 7.3 & 99 & 96 & 3500 & 220 & 0.0 & 0.6 & 0.6 grams $\mathrm{NaCl}$ in 20 cc. vomitus. Dry skin. \\
\hline Pal & 14 & 6.7 & 7.3 & 101 & 100 & 3400 & 5 & 5.0 & $0.0+$ & Dry skin; low blood pressure; jaundice; rest- \\
\hline & 5 & & 5.9 & 100 & 107 & 1800 & 190 & 0.0 & 0.6 & None. \\
\hline $\begin{array}{l}\text { Leng } \\
\text { Ga }\end{array}$ & $\begin{array}{l}14 \\
15\end{array}$ & $\begin{array}{l}6.2 \\
6.7\end{array}$ & $\begin{array}{l}6.4 \\
6.4\end{array}$ & $\begin{array}{r}99 \\
103\end{array}$ & $\begin{array}{l}102 \\
105\end{array}$ & $\begin{array}{l}3600 \\
3600\end{array}$ & $\begin{array}{r}520 \\
1075\end{array}$ & $\begin{array}{l}7.5 \\
7.5\end{array}$ & $\begin{array}{l}2.5 \\
1.3\end{array}$ & $\begin{array}{l}\text { None. } \\
\text { None. }\end{array}$ \\
\hline Ger & 16 & 5.9 & 6.8 & 104 & 101 & 3700 & 100 & 10.0 & 0.2 & Skin slightly dry. No other reaction. \\
\hline $\begin{array}{l}\text { Pet } \\
\text { Slo }\end{array}$ & 16 & $\begin{array}{l}6.8 \\
5.6\end{array}$ & $\begin{array}{l}7.2 \\
5.9\end{array}$ & 104 & $\begin{array}{r}97 \\
110\end{array}$ & $\begin{array}{l}2800 \\
3300\end{array}$ & $\begin{array}{r}130 \\
25\end{array}$ & $\begin{array}{r}7.0 \\
15.0\end{array}$ & $\begin{array}{l}1.2 \\
0.2\end{array}$ & $\begin{array}{l}\text { Restless. Otherwise uneventful. } \\
\text { Restless; dry skin. }\end{array}$ \\
\hline Ro & 17 & 6.8 & 7.1 & 88 & 91 & 4050 & 140 & 7.0 & 0.4 & Restless; dry skin; low blood pressure. Other- \\
\hline & 16 & 6.7 & 6.7 & 106 & & 4000 & 734 & 10.0 & 4.1 & $\begin{array}{l}\text { wise } \\
\text { None. }\end{array}$ \\
\hline $\begin{array}{l}\text { Sko } \\
\text { McGo }\end{array}$ & 21 & 6.0 & 6.6 & 103 & 106 & 5100 & 480 & 15.0 & 3.3 & None. \\
\hline Vic & 22 & $\begin{array}{l}5.1 \\
6.2\end{array}$ & $\begin{array}{l}0.1 \\
5.8\end{array}$ & $\begin{array}{r}104 \\
97\end{array}$ & $\begin{array}{l}103 \\
108\end{array}$ & $\begin{array}{l}4350 \\
6200\end{array}$ & $\begin{array}{r}430 \\
1688\end{array}$ & $\begin{array}{l}10.0 \\
20.0\end{array}$ & 3.8 & None. \\
\hline DFa & 16 & 6.4 & 6.5 & 96 & 91 & 3000 & 100 & 5.0 & 0.1 & 0.8 grams in $400 \mathrm{cc}$. vomitus. Skin dry at \\
\hline $\begin{array}{l}\mathrm{RFa} \\
\mathrm{Al}\end{array}$ & $\begin{array}{l}16 \\
14\end{array}$ & $\begin{array}{l}6.6 \\
6.8\end{array}$ & $\begin{array}{l}6.9 \\
7.4\end{array}$ & $\begin{array}{r}101 \\
84\end{array}$ & $\begin{array}{r}105 \\
89\end{array}$ & 4000 & 1080 & 10.0 & 2.3 & $\begin{array}{l}\text { end of treatment. } \\
\text { Restless; slight jaundice. }\end{array}$ \\
\hline Creid & 14 & 6.4 & 6.4 & 98 & 106 & 3600 & 280 & 10.0 & 1.1 & Pallor but no other reaction. \\
\hline
\end{tabular}


ride were given daily to supplement that in the diet, only about 5 grams would appear in the first and second days' output, and not until the third or fourth day would the output approach or pass the 15 gram excess of sodium chloride administered.

It soon became apparent that the empirical administration of 1 gram of sodium chloride plus 500 to $600 \mathrm{cc}$. of water per hour by mouth was approximately the basic requirement for the proper management of the average patient at $41.5^{\circ} \mathrm{C}$. for periods of 10 to 20 hours' duration, and that additional sodium chloride must be given following treatment. Reactions became less frequent on this routine but occasionally occurred when least expected.

A survey of the total protein changes in the 50 cases mentioned above showed (Table I) that there was a good deal of consistency between the rise in serum protein values and the occurrence of reactions bordering on collapse. Cases showing serum protein values of 7.0 grams or lower usually did well. Those with values above 7.0 grams usually showed some symptoms of the collapse syndrome. Occasionally, a patient with serum protein values of 8.0 grams at the end of treatment did well, yet he might show a severe chloride deficit in his urine during the succeeding days. The rise in serum protein seems to be a result of reduction of plasma volume following the obviously large and rapid losses of electrolytes and water as a result of profuse sweating (22, $23)$, rather than a gain in circulating protein from the body stores $(24,25)$ although some exchange can readily occur. It is difficult for us to believe that a negative nitrogen balance (26) occurs during the febrile state. Without evidence to the contrary, it is probable that the total quantity of circulating plasma protein remains fairly constant $(27,24,25)$ during the treatment period. The plasma chloride and water, on the other hand, are subject to tremendous exchange through ingestion, excretion (sweat and urine), and exchange with the extracellular spaces $(23,37)$. Total protein values indicate at least the trend of concentration of the blood, and over the short period required are thus a relative measure of what is happening to the circulating plasma volume. In turn, this is probably a reflection to some extent of the state of the interstitial store of fluid and electrolytes (28 to 30 ).

The determination of the total protein is too unwieldy a procedure to be used as a quick, simple guide while treatment is underway and quick decisions must be made. The plasma specific gravity technique, done by the pyknometer gravimetric method (31), on the other hand, is simple, rapid (10 to 15 minutes), and requires little blood.

The protein content has the greatest influence upon the specific weight of the plasma or serum. During the treatment, total protein elevations of 15 per cent (from 5.9 to 6.8 grams) will occur, and the chloride will change about 2 per cent (104 to $101 \mathrm{~m}$. eq./L.), or less than the accuracy of both the chemical and specific gravity methods. This protein change represents a change in plasma specific gravity from 1.0243 to 1.0270 .

Plasma specific gravity data have been consistently taken for the last 5 years and over 4500 determinations give a good catalogue of the normal and abnormal states encountered (Tables II and III). The ranges in Table I are similar to those reported by Moore and Van Slyke (32). We have now had enough experience in the interpretation of these data to use plasma specific gravity as the principle guide to the adjustment of the fluid and salt requirements of the patient during our routine treatments of 15 hours at $41.5^{\circ} \mathrm{C}$. Occasional individual and unexplainable variations may be encountered so that one must proceed with the treatment more cautiously in such cases.

$\begin{array}{lr}\text { Hydration status } & \text { TABLE II } \\ \text { Dehydration } & \text { Plasma specific gravity } \\ \text { Normal } & \text { Greater than } 1.0290 \\ \text { Low } & 1.0255 \text { to } 1.0290 \\ \text { Overhydration } & 1.0233 \text { to } 1.0255 \\ \text { Edema zone } & \\ \text { Edema } & 1.0225 \text { to } 1.0233 \\ \end{array}$

Judging by the plasma specific gravity standard, many patients are admitted to the hospital with their fluid stores near depletion. Failure to replenish this store by the administration of salt and water before treatment has resulted in the past in many cases of dehydration, even during short fever treatments. Therefore, in preparing a patient for fever treatment, it is advantageous to give 12 to 15 grams of salt plus fluid ad lib. (3 to 4 liters) to the patient on the day before 
TABLE III

Characteristic changes in the plasma specific gravity

Most of these patients were in bad physical condition and the worst risks are marked with an $\left(^{*}\right)$. They were treated at a lower temperature of $40.5^{\circ}$ to $41.0^{\circ} \mathrm{C}$. because of this. Extrapolations are from Peters and Van Slyke (33).

\begin{tabular}{|c|c|c|c|c|c|c|c|c|c|c|c|}
\hline \multirow{2}{*}{ Patients } & \multirow{2}{*}{$\begin{array}{c}\text { Treated at } \\
\mathbf{4 1 . 5} 5^{\circ} \mathrm{C} .\end{array}$} & \multicolumn{3}{|c|}{ Plasma specific gravity } & \multicolumn{3}{|c|}{ Extrapolated total proteins } & \multicolumn{3}{|c|}{ Blood chloride } & \multirow{2}{*}{ Reaction } \\
\hline & & Start & 5 hours & End & Start & 5 hours & End & Start & 5 hours & End & \\
\hline & hours & & & & \multicolumn{3}{|c|}{ grams per $100 \mathrm{cc}$. } & & \multicolumn{2}{|c|}{ m. eq. per $L$. } & \\
\hline Cal & 10 & 1.0280 & 1.0253 & 1.0328 & 7.2 & 6.4 & 8.2 & 106 & 102 & 106 & $+t+$ \\
\hline Mais & $6^{*}$ & 1.0243 & 1.0263 & 1.0268 & 5.9 & 6.4 & 6.6 & 104 & 103 & 104 & + \\
\hline & 10 & 1.0247 & 1.0258 & 1.0262 & 6.0 & 6.4 & 6.6 & 101 & 100 & 97 & +- \\
\hline Bo & 9* & 1.0278 & 1.0288 & 1.0270 & 7.1 & 7.4 & 6.8 & 102 & 99 & 99 & \\
\hline & 10 & 1.0254 & 1.0250 & 1.0251 & 6.2 & 6.1 & 6.2 & 103 & 101 & 98 & +- \\
\hline Sar & 10 & 1.0291 & 1.0328 & 1.0300 & 7.4 & 8.5 & 7.9 & 105 & 102 & 100 & +- \\
\hline Go & $10^{*}$ & 1.0254 & 1.0283 & 1.0278 & 6.3 & 7.2 & 7. & 108 & 105 & 106 & + \\
\hline & 11 & 1.0265 & 1.0271 & 1.0293 & 6.7 & 6.9 & 7.6 & 111 & 106 & 107 & +- \\
\hline Ko & 11 & 1.0271 & 1.0275 & 1.0285 & 6.9 & 7.0 & 7.4 & 105 & 101 & 100 & +- \\
\hline $\mathrm{Ha}$ & 11 & 1.0284 & 1.0284 & 1.0284 & 7.4 & 7.5 & 7.4 & 103 & 100 & 100 & 0 \\
\hline Mu & $5^{*}$ & 1.0262 & 1.0260 & & 6.6 & 6.5 & & 103 & 99 & & 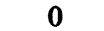 \\
\hline Sin & 10 & 1.0298 & 1.0276 & 1.0294 & 7.7 & 7.1 & 7.9 & 114 & 110 & 91 & +- \\
\hline Moul & 15 & 1.0269 & 1.0271 & 1.0281 & 6.8 & 6.9 & 7.1 & 110 & 108 & 104 & +- \\
\hline
\end{tabular}

\footnotetext{
$0=$ no reaction.

$+-=$ dry skin, moderately low blood pressure (80 to $70 \mathrm{~mm}$. systolic) at end of treatment.

$+=$ restlessmess, dry skin, low blood pressure, mild prostration.

$+++=$ collapse as treatment ended; recovered, slight jaundice.
}

All of these patients were cases of advanced paresis with a bad prognosis, and either would not have been accepted for treatment previous to 1941 because of the bad risk or would have been treated with the knowledge gained from previous experience that one or more deaths would ensue from collapse. The preliminary treatment at the lower temperature improved them enough to enable three of them $\left(^{*}\right)$ to tolerate the full treatment of 10 hours at $41.5^{\circ} \mathrm{C}$. later.

treatment. Most of this water must be stored since the patient usually gains from 3 to 4 kilograms in weight over night, and the plasma specific gravity reading may drop 10 to 20 per cent. Longer periods of salt administration may produce catharsis and gastric irritation, or even some actual overhydration which may be accentuated during treatment unless fluids and salt are later restricted. Occasionally, the administration of 15 grams of salt and appropriate amounts of water over a 3-day period previous to treatment has resulted in a diuresis at the end of this time which has depleted the patient, just before treatment, of more water and salt than was stored. Thus, some patients were near overhydration at the start of treatment and others were actually dehydrated. Prolonged treatments at $41.5^{\circ} \mathrm{C}$. are not feasible as a routine procedure without properly "filling" the body's store with salt and water, yet when the adjustment is properly done, such long treatments may be accomplished with surprising ease and safety.

Originally, plasma specific gravity measurements were made daily for 3 to 4 days prior to and following treatment, and as often as hourly during the course of the fever. Now, however, after one day of salt administration, usually of 15 grams, a determination is made immediately prior to the induction of a prolonged fever of 15 hours at $41.5^{\circ} \mathrm{C}$., and another 5 to 7 hours after the beginning of treatment, and a third at the close of treatment. These 3 determinations are usually sufficient. If there is any abnormal change in the patient during or after fever, plasma specific gravity measurements are made as required.

During the process of treatment itself, 400 to $500 \mathrm{cc}$. of heavily sugared weak tea, dilute fruit juice or water are given per hour plus 1 gram of salt in $100 \mathrm{cc}$. of water per hour for the first 4 to 5 hours. Throughout the rest of the treatment, fluids are given at about the above rate but $1 \mathrm{gram}$ of salt is given every other hour or not at all, as indicated by the plasma specific gravity readings. Unless otherwise indicated, all of the fluids and salt are given by mouth.

During the past 48 months, up to July 1942, 406 prolonged treatments employing the "radiant energy" cabinet have been guided by the plasma specific gravity measurements as determined by the pipette pyknometer method (31). In the last 100 fever treatments of 10 to 27 hours at $41.5^{\circ} \mathrm{C}$. done just previous to 1939, there was one death, 
and approximately 28 per cent of the cases displayed dehydration severe enough to give clinical signs and rises of 15 to 30 per cent in the total protein values. In the next 100 cases given 10 to 18 hours of fever at $41.5^{\circ} \mathrm{C}$. during 1939 to 1940 , while we were adjusting the fluid and salt intake in accordance with the plasma specific gravity values, there was one death (reported below) and approximately 20 per cent of the cases were to some degree dehydrated. Between 1940 and July 1942 , however, over 300 cases have been treated with less than 10 per cent of them falling in the dehydration range. There were no mortalities in this group. Many of these patients were paretics in such poor physical condition that they would not have been accepted for treatment previous to 1940 (Table III). In some instances, the administration of fluid has been overdone and a new syndrome of overhydration produced which, in many respects, causes symptoms resembling dehydration.

During the period of fever treatment it has been found that the patient's body fluid status, as indicated by the plasma specific gravity readings, may be divided into any one of 3 general groups:

1. The plasma specific gravity level may start at and be maintained well within the normal range of 1.0255 to 1.0290 by the proper fluid and salt administration.

2. The specific gravity levels may be already high or may rise during treatment, indicating that dehydration is present. This must be corrected or the treatment stopped if this trend persists or increases.

3. The plasma specific gravity may fall from the initial value, indicating plasma dilution. This may represent adequate or excessive fluid storage, in which situation, fluid and salt should be restricted.

Characteristic illustrations of these variations are presented in 3 classifications: (1) the well controlled or satisfactory group; (2) the dehydration group; and (3) the overhydration group.

\section{SATISFACTORY GROUP}

The criteria for classification within this group are: (1) tolerance of the patient to the therapy, with no marked irregularities of pulse, respiration, or blood pressure, and complete recovery by the following day. In cases treated routinely for periods varying from 5 to 18 hours at $41.5^{\circ} \mathrm{C}$., the respirations may be from 20 to 40 per minute, the pulse 140 to 160 per minute. During the induction and the first hour of fever, the systolic blood pressure may rise 20 to $40 \mathrm{~mm}$. $\mathrm{Hg}$ higher than at the start of treatment. During the latter part of therapy, the systolic pressure may fall to 100 or $120 \mathrm{~mm}$. $\mathrm{Hg}$ and rarely goes lower than $20 \mathrm{~mm}$. below the patient's normal blood pressure level. (2) Nausea, vomiting, or diarrhea are absent. The output of urine containing some sodium chloride continues at regular intervals. There is a "normal" amount of sweating although some patients sweat more profusely than others. Neither age, the disease for which the patient is being treated, nor any other obvious reasons seem to be related to the amount of sweating present. (3) The patient is able to sleep during most of the treatment without narcosis and with a minimum of restlessness when awake. (4) The plasma specific gravity is maintained in the normal range of 1.0255 to 1.0290 . (5) In this group there were 369 treatments, or 91 per cent of the entire series.

Four selected cases have been chosen to demonstrate the various changes in plasma specific gravity which may occur during a satisfactory fever treatment at high temperatures. The large although variable maintenance requirements of both salt and water are of particular significance in estimating the needs of a case in order to prevent symptoms of advancing dehydration from any cause. The gain or loss in body weight, if any, can be about $2 \mathrm{kgm}$. without causing clinical symptoms or deflecting the plasma specific gravity out of the normal range. This weight loss is readjusted by the patient within a few days following treatment. The urine excretion varies between $1 / 4$ and $1 / 7$ of the fluid intake. The rôle of the sweat glands as an excretory organ of high order during fever thus becomes apparent.

Before the advent of sulfanilamide, fevers of 15 to 27 hours' duration at $41.5^{\circ} \mathrm{C}$. were not unusual. A single prolonged fever is still often given for the treatment of refractory cases of gonorrhea $(32,34)$, and is also being used in our clinic for the treatment of paresis, whenever feasible. Four selected cases of rheumatoid arthritis were given experimental 48 -hour treatments at a temperature of $39.5^{\circ} \mathrm{C}$. In these cases, where 


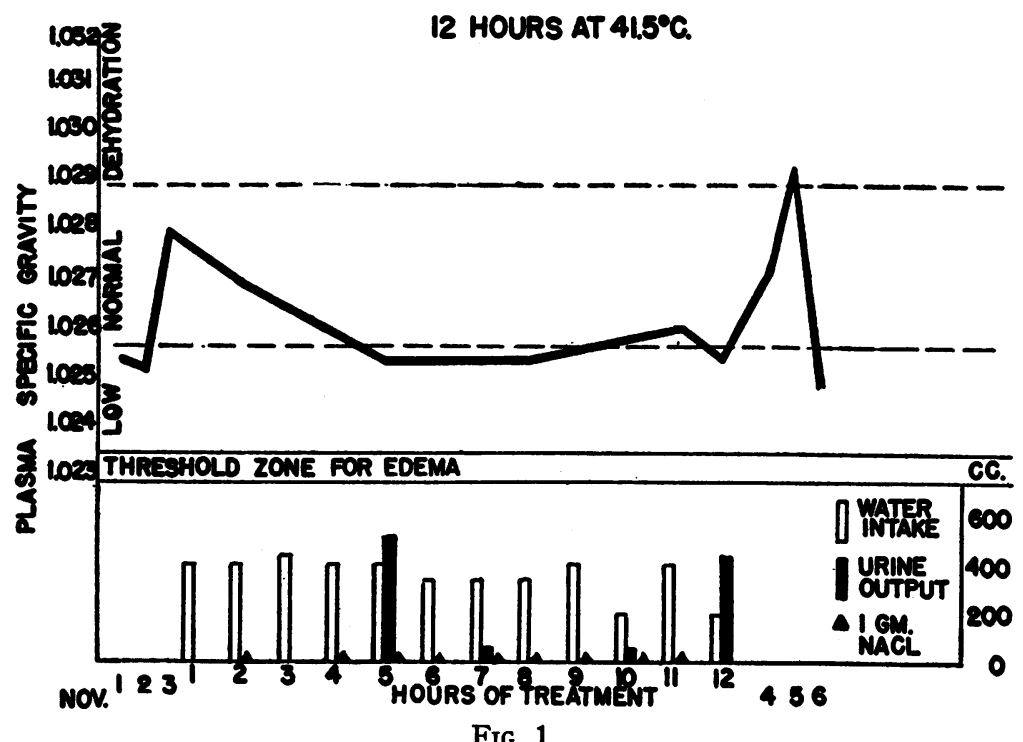

FIG. 1

sweat loss is of such great magnitude, it is especially important that the control of fluids and electrolytes be adequately and safely guided.

Case Number 1 (Figure 1): This case illustrates a routine 12 -hour treatment, at a rectal temperature of $41.5^{\circ} \mathrm{C}$., of a 40-year-old woman with latent syphilis. The patient had an intake of $4220 \mathrm{cc}$. of fluid and $10 \mathrm{grams}$ of salt, with a urine output of $630 \mathrm{cc}$. Blood pressure varied but slightly from its original level (average pulse 120, respirations 27). Interesting to note is the overnight rise of specific gravity between November 2 and November 3 (the day of treatment). This has frequently occurred and is probably due to excessive kidney excretion as a result of nervousness in an apprehensive patient at the prospect of treatment the next day. With adequate administration of fluid during the first few hours of treatment, the plasma specific gravity was soon brought down to the optimum level where it remained throughout the treatment. The patient tolerated the therapy extremely well but for one small emesis, some nervousness and apprehension. Her condition at the end of treatment was excellent. The rise and fall of her plasma specific gravity during the 3 days following treatment is commonly found and probably represents an overcompensation during readjustment of the water balance mechanism which has been subjected to a severe strain by the fever.

Case Number 2 (Figure 2): This patient was a 52 year-old paretic who was treated for 10 hours at a temperature of $41.5^{\circ} \mathrm{C}$. The plasma specific gravity level the

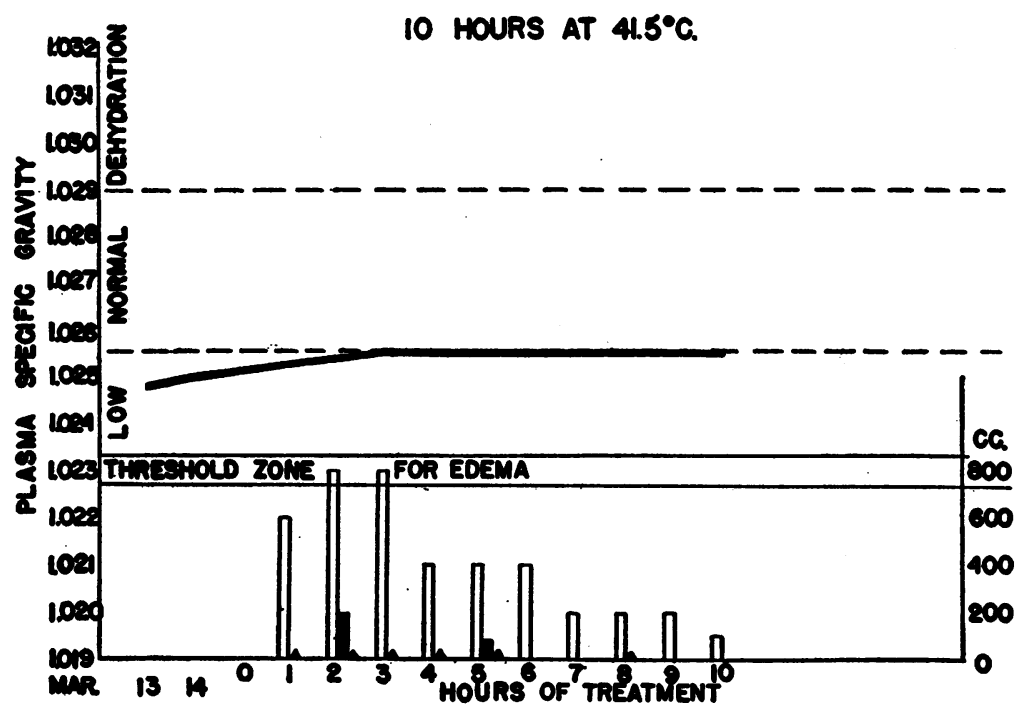

FIG. 2 


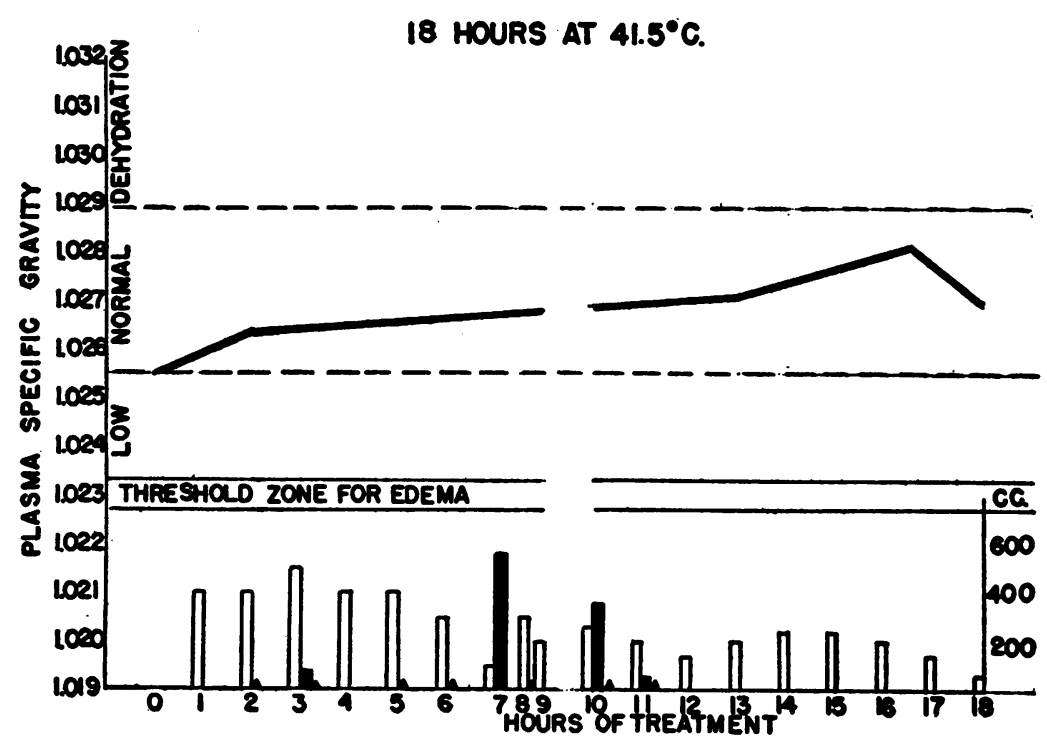

FIG. 3

day prior to treatment showed that he had stored water in response to the prefever hydration regime. There was little change from this level overnight. Since most of the patients showed a tendency to dehydrate during the first few hours of fever, fluids were forced during this period. At the third hour, the plasma specific gravity level was still optimum so gradually the fluids were reduced until it was found that the plasma specific gravity levels at the 8 th and 10 th hours could be maintained by only $200 \mathrm{cc}$. of fluid per hour and $1 \mathrm{gram}$ of salt. His total fluid intake was $4500 \mathrm{cc}$. and 6 grams of salt were given. Urinary output was 280 cc. He perspired markedly throughout treatment. His weight at the start of treatment was 92.6 $\mathrm{kgm}$. and at the end was $89.3 \mathrm{kgm}$. His average pulse and respirations were 100 and 32, respectively. Blood pressure showed a gradual downward trend from $150 / 76$ to $90 / 46$ at the close of treatment. The patient tolerated the fever well and his post-fever course was uneventful.

Case Number 3 (Figure 3): This chart illustrates the satisfactory treatment of a 43-year-old male, treated for gonorrheal arthritis at $41.5^{\circ} \mathrm{C}$. for 18 hours. His total fluid intake was $4700 \mathrm{cc}$. and he received 14 grams of salt. His urinary output was $900 \mathrm{cc}$. and he vomited a total of about $900 \mathrm{cc}$. in small amounts at various time intervals, reducing his actual intake to $3600 \mathrm{cc}$. Sweating was intense. His clinical status remained within normal limits. It may be seen from the chart that there is a slow gradual tendency for his plasma specific gravity to rise, yet it did not reach a high level at any time. He was adequately prepared, had stored fluid well, and with the administration of nearly the proper amount of fluid and salt during the treatment, his dehydration did not approach a dangerous level. His clinical condition at the close of treatment was good.

Case Number 4 (Figure 4) : A 48-year-old woman with infectious arthritis was given a 48-hour treatment at $39.5^{\circ} \mathrm{C}$. Her intake over this period was $13,840 \mathrm{cc}$. of fluid and 29 grams of salt. The urinary output was $\mathbf{5 4 6 0}$ cc. and there was no emesis. This case was very well controlled. Water and salt intake was reduced after 26 hours of treatment, and the plasma specific gravity rose to 1.0278 by the 34 th hour. The fluids were therefore proportionally increased and a corresponding fall in plasma specific gravity was noted. The specific gravity level during the last 8 hours was near the optimum of 1.0255 . That she was well hydrated and the interstitial reservoirs well filled was indicated not only by the plasma specific gravity levels but also by the continued sweating, urine output, and a normal blood pressure, and no weight loss. Her reactions are typical of 3 others similarly treated.

\section{DEHYDRATION GROUP}

The criteria for classification in this group are: (1) The psychic intolerance of the patient to therapy, which increases dangerously if the dehydration state persists. Depending somewhat upon the rate of development of the dehydration state, the urine output diminishes and then ceases. Sweating stops. The patient may show fluctuations in the rate of pulse, respiration, and blood pressure. (2) If the dehydration is severe, the respirations increase and become shallow, cyanosis appears, the pulse rises to 160 or 170 , and the systolic pressure begins to fall rather rapidly. The pulse pressure increases and may finally disappear. The skin is bluish and often cold. The extremities are cold, even with a rectal temperature of $41.5^{\circ}$ to $42.5^{\circ} \mathrm{C}$. (3) Nausea may be present but only after the patient has over-com- 
A. 6. 74039

$12-19-38$

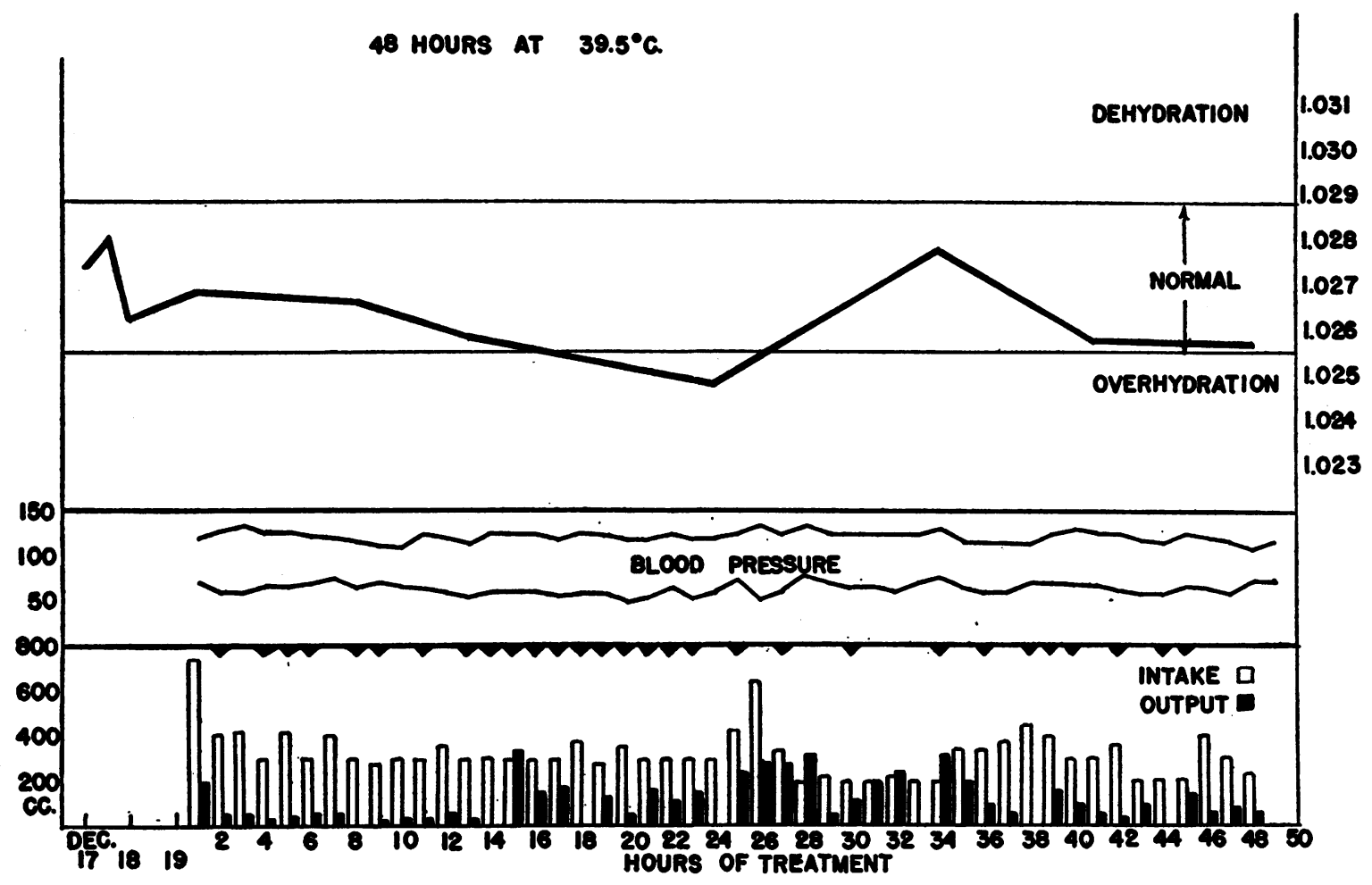

FIG. 4

pensated his thirst by the amount of fluid without salt that the stomach can care for. The emesis contains little or no chloride. (4) Extreme restlessness ensues and maniacal trends develop to the time of unconsciousness when the collapse or shock state becomes fully evident. Maniacal states are accompanied by physical excretion which is accompanied by a rise in temperature. It usually defeats attempts to cool the patient down. Such maniacal states are now controlled by the use of 0.5 gram to 2.0 grams of Evipal intramuscularly or intravenously, which allows us to reduce the temperature before a dehydration collapse ensues yet still permits the patient to recover consciousness rapidly enough to cooperate in taking fluids by mouth. In Case Number 5, the clinical signs of collapse came on too rapidly during the maniacal state to alter the course of the treatment in time. Had we had more experience with the plasma specific gravity method at that time, the development of the dangerous dehydration state would have been appreciated earlier and precautions would have been taken to prevent it. (5) When the clinical evidences of dehydration are present, the plasma specific gravity has always been in the dehydration range above 1.0290 . In the average case, a change to the high normal specific gravity level, or a rise from normal into the dehydration zone, indicates the possible onset of dehydration well before there is any clinical evidence for it. (6) There have been situations, however, when treatment has been continued even with the specific gravity reading in the dehydration range throughout the entire course of treatment. In such cases (Numbers 7 and 8), the situation was apparently otherwise normal since sweating and urine output continued, and the clinical status was within the normal range. This is in some way related to a seasonal variation which will be discussed later in this paper. (7) A prolonged period of inadequate supply of salt and fluid at these high temperatures in the presence of dehydration may also result later in the appearance of jaundice which is apparently due to damage to the liver. The jaundice may be severe and add days to the hospitalization of the patient. This is now rarely seen since the fluid and salt balance have been controlled. Jaundice is little 
affected by carbohydrate administration alone, but responds more rapidly to adequate saline administration of from 15 to 20 grams daily plus plasma protein transfusions. (8) Recovery from advanced dehydration states may take from 3 to 10 days, even with adequate water and salt administration. The symptoms are anorexia, vomiting, malaise, and occasionally anuria and fever. The loss of weight may be as much as 4 to 6 kgm. (9) In this group, there were 28 treatments, or 6 per cent of the entire series of cases. Three selected cases have been chosen to illustrate the various changes in plasma specific gravity, etc., which occur in the state of dehydration.

Case Number 5 (Figure 5): One of the early cases in this series demonstrates quite well how rapidly dehydration may develop with little warning and progress to a fatal termination with collapse or shock. This patient was a 41-year-old obese male, in poor physical condition, who was treated at $41.5^{\circ} \mathrm{C}$. for advanced central nervous system syphilis. The fluid intake was not guided by plasma specific gravity measurements at this time, and it is noted that there was actually very little change in his level during the prefever stage, showing that he had probably not increased his fluid reserve. Overnight before treatment, the plasma specific gravity level rose from 1.0264 to 1.0278 (upper normal range). Thus, when fever was started the profuse sweating which ensued soon depleted his fluid and salt stores to a dangerous level. Clinically, he seemed to be doing poorly from the onset of therapy although his blood pressure was maintained satisfactorily. Two hours after the start of therapy his temperature was $41.5^{\circ} \mathrm{C}$., and shortly afterward the patient developed an uncontrollable mania. His condition rapidly became critical with ensuing collapse and coma. Up to that point he had received $900 \mathrm{cc}$. of fluid and $1 \mathrm{gram}$ of salt, the usual amount. There was then an emesis of 100 cc. followed by a sudden and complete cessation of sweating. The pulse became barely perceptible and the blood pressure could not be obtained. He was given $500 \mathrm{cc}$. of Ringer's solution subcutaneously and $1000 \mathrm{cc}$. intravenously but he expired 2 hours later, 7 hours after the start of treatment, and despite all efforts to revive him. At the 4th hour (even after some of the infusion fluid had been given), the plasma specific gravity was 1.0327 . The collapse of this man was obviously precipitated by the onset of his maniacal state while he was in the lower and early stages of dehydration. Post mortem examination revealed no definite cause of death.

Cases Number 6 and 7 (Figures 6 and 7): In February 1939, 2 cases were treated on the same day. Both were young men in good physical condition. They had both appeared in the Syphilis Clinic on the same day with acute primary and secondary lesions of syphilis. Both had temperatures varying from $38.0^{\circ} \mathrm{C}$. to $38.5^{\circ} \mathrm{C}$. and appeared moderately acutely ill. It was decided to treat them with fever, neither having had any chemotherapy. The day previous to treatment it was found that the plasma specific gravity levels of both men were in the high level for the normal range. Fluids were not well stored, probably because of their febrile condition and also perhaps because of the seasonal factor.

At about the time their induced fevers had reached $41.5^{\circ} \mathrm{C}$., both patients showed what were ordinarily considered to be dangerously high plasma specific gravity levels. There was an immediate increase in the administration of fluid and salt for both patients. "S" responded fairly well clinically, but " $R$ " failed to accept his fluids properly so the cabinet was opened at the 4th hour and

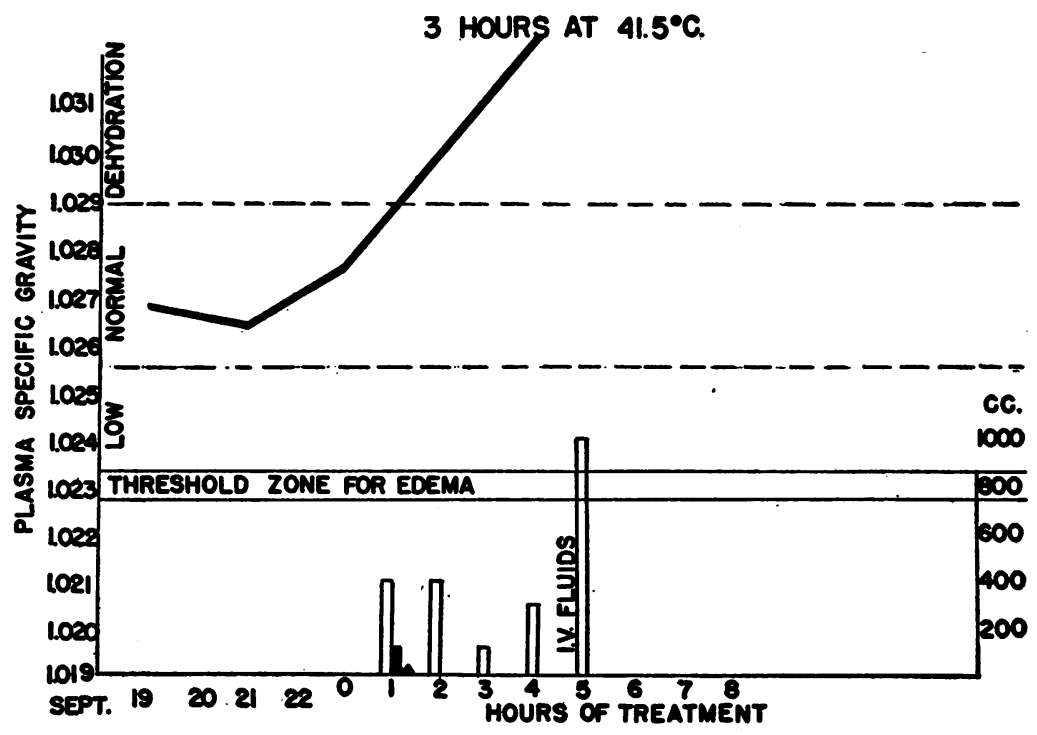

Fig. 5 


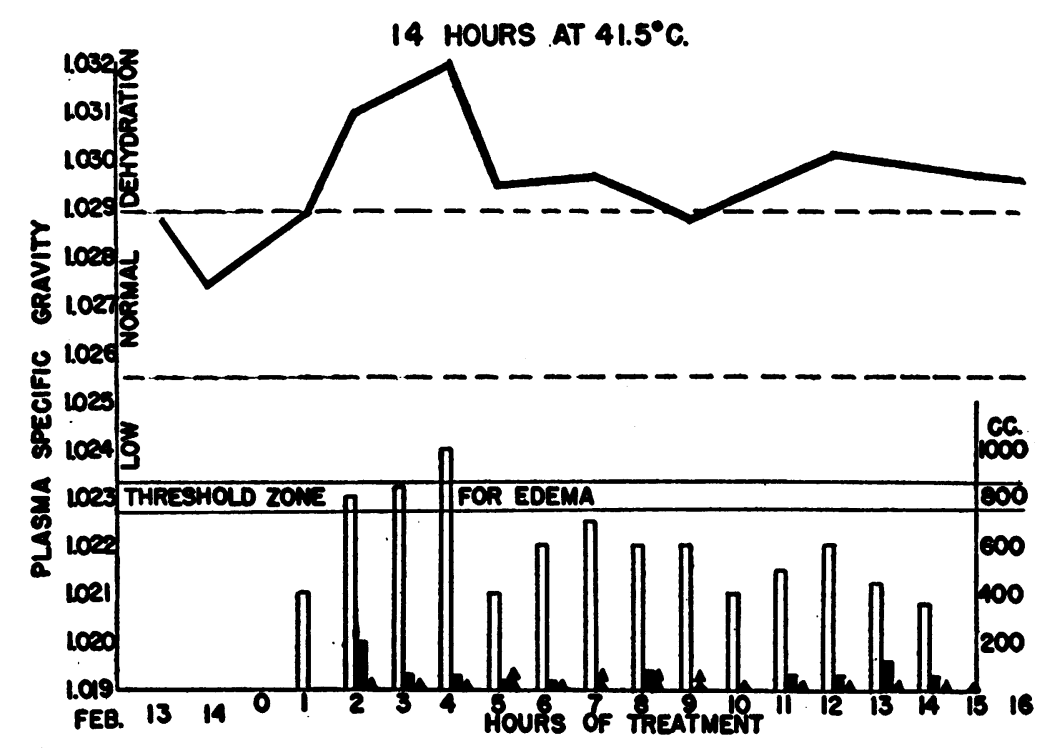

FIG. 6

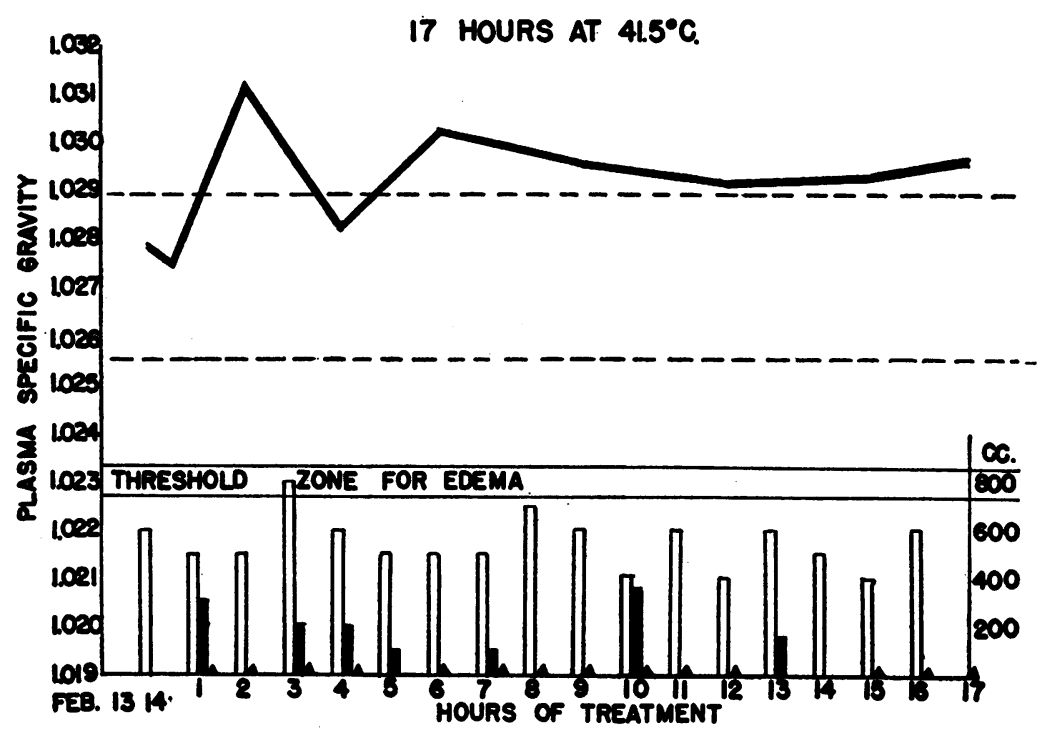

FIG. 7

his temperature brought down slowly. After a brief time, his clinical condition improved and the treatment was resumed at $40.5^{\circ} \mathrm{C}$. Having passed this critical period, both cases continued to receive their treatment, " $R$ " for a total of 14 hours, and " $S$ " for 17 hours, at $41.5^{\circ} \mathrm{C}$. The plasma specific gravity readings for both continued just above the normal range during this period. This would seem to indicate that their interstitial reservoirs were apparently near depletion, yet both of these patients had profuse sweating and appeared to react normally. " $R$ " had a total intake of $9050 \mathrm{cc}$. and 17.5 grams of salt, with a urinary output of $950 \mathrm{cc}$. His blood pressure, pulse, and respirations were well sustained. Toward the end of treatment, he ceased sweating and treatment was stopped. He recovered promptly from the treatment without sequelae. " $S$ " had a total intake of $8700 \mathrm{cc}$. and 16 grams of salt with a urinary output of $1185 \mathrm{cc}$. His clinical status also showed little variation from the normal. These cases indicate that even though undesirable levels are present, treatment may progress with caution as long as the plasma specific gravity levels are carefully followed.

Since these 2 cases not only continued to sweat but also had rather large volumes of urinary output, we were at a loss to explain fully their good condition at such high specific gravity levels. Assuming that a seasonal shift in 
the plasma specific gravity level had occurred, as suggested above, it may be that these patients were actually maintained on a narrower fluid reservoir margin at this period of the year. These 2 cases are good examples of several which have occurred during this period of the year.

\section{OVERHYDRATION GROUP}

The criteria for classification in this group are: (1) The psychic intolerance of the patient to therapy as long as the overhydration state persists. Irregularities of pulse, respiration, and blood pressure are noted. The respiration rate may increase and often becomes stertorous. The pulse may be rapid (120 to 160 per minute). The blood pressure may first rise to hypertensive levels and then as collapse ensues, it may fall below $80 \mathrm{~mm}$. $\mathrm{Hg}$ systolic. (2) Nausea and vomiting appear rather early. Diarrhea may also be present. Strangely enough, the urine is first as copious as is the diaphoresis but as the overhydration state becomes more extreme, the renal mechanism fails and sweating ceases. The skin may be very dry, with no evidence of perspiration in any area. The extremities are cold and blue, and the patient actually appears dehydrated. (3) Early in the overhydration state, there is no evidence of gross edema. As the state becomes more severe, however, puffiness is noted about the face and eyes, and gross edema appears which may even become general, involving the ankles, legs, sacrum, and arms. (4) The patient becomes rest- less, irritable, and emotionally unstable. Later, muscular twitchings, athetoid movements of the arms and legs (not tetany) may appear. In the advanced states of overhydration, severe and almost continuous grand mal seizures are present. It may be necessary to administer intravenous Evipal to stop these serious seizures, as is done for the mania accompanying dehydration states. The body temperature should be reduced as quickly as possible, since below $40^{\circ} \mathrm{C}$. these central nervous system phenomena usually disappear without the aid of anesthesia. Recovery after treatment is slow, for the patient is in a "water logged" state. Mental confusion and irritability often last for 2 to 7 days. This is frequently accompanied by a spontaneous fever of several degrees. These mental symptoms have not been observed in patients who are dehydrated. (5) The gain in weight may be as much as 5 or $6 \mathrm{kgm}$. which are later lost by diuresis. (6) The plasma specific gravity measurements in these cases of overhydration are below 1.0245. A rapid drop from high normal to this level may present some symptoms. The plasma specific gravity trends show very early any tendency to overhydration. Thus, the serious overloading of the system with salt and water may be avoided. This measurement is of great aid in differentiating between overhydration collapse and dehydration collapse. In fact, in cases where sweating is absent, this may be the only means of differentiating between

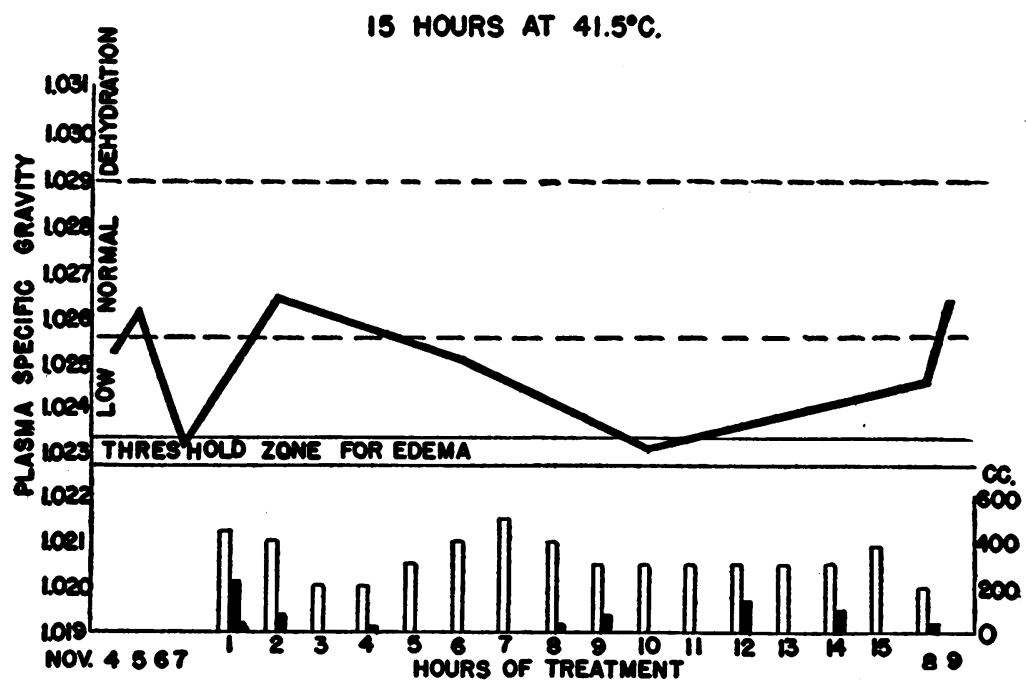

Frg. 8 


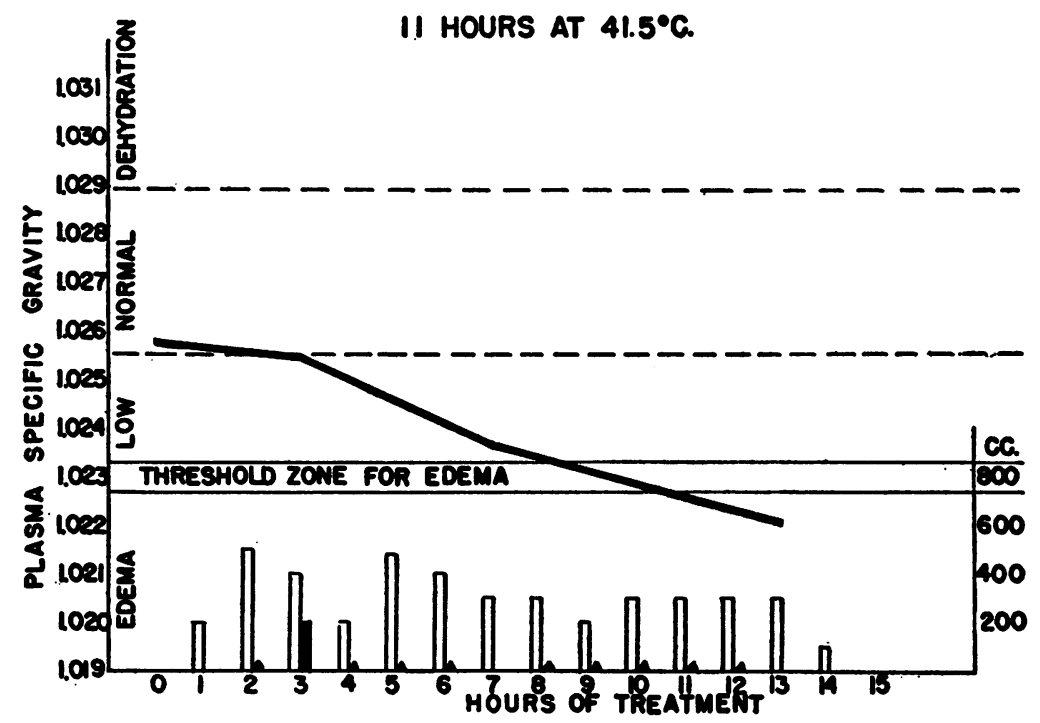

FIG. 9

the two states. The state of overhydration collapse or shock was entirely new to us and we have sometimes been guilty of inducing it in our attempt for optimum adjustment. (7) In this group were 9 definite cases, or 3 per cent of the entire series. Three cases have been chosen to illustrate the changes brought about during the development of a state of overhydration.

Case Number 8 (Figure 8): Patient E. L. developed a state of moderate overhydration. A 23-year-old female with gonorrheal arthritis and cervicitis was treated for 15 hours at $41.5^{\circ} \mathrm{C}$. Intake was $5200 \mathrm{cc}$. of fluid and a total of 12 grams of sodium chloride. The urine output was only $665 \mathrm{cc}$. Although definitely overhydrated (showing a plasma specific gravity of 1.0232) the patient did not become edematous nor show changes in blood pressure. In general, she tolerated the procedure fairly well and recovered promptly.

Case Number 9 (Figure 9) : A 21-year-old female with chorea was given 11 hours of fever at $41.5^{\circ} \mathrm{C}$. She received a total of $4300 \mathrm{cc}$. of fluid and 9 grams of salt over this period of time. Her urinary output was $365 \mathrm{cc}$, which was unusually scant as compared with the large intake. Sweating was only moderate. Here also, specific gravity readings were not yet used to govern the fluid intake, and from the 7 th to the 13th hours, the plasma specific gravity dropped from 1.0237 to 1.0212 . In this case, the patient had gross edema, with swelling of the face and eyelids, and pitting edema of the sacrum and legs, indicating that fluids had been forced beyond the body needs. This incident was in accord with the findings of Baird and Haldane (35) who showed that the administration of sodium chloride in excess of the ability to excrete it produced visible edema. Other than the water- logging, her course was favorable. There was some postfever nausea and vomiting, and she did seem somewhat more exhausted by the fever treatment than does the average well-controlled case.

Case Number 10: This case developed a severe and almost fatal overhydration, with a clinical syndrome almost indistinguishable from dehydration. A 24-year-old female with advanced congenital paresis, confused, emotionally unstable, agitated, was treated after the usual preparation. She tolerated the treatment at $41.5^{\circ} \mathrm{C}$. fairly well up to the 10th hour when she began to have grand mal seizures which passed into status epilepticus, at which time the treatment was terminated. By this time, her intake was $5300 \mathrm{cc}$. of fluid, urine output was $80 \mathrm{cc}$. with moderate sweating. She received 0.5 gram of Evipal intravenously and 0.5 gram of Evipal intramuscularly without affecting the attacks. In order to stop the muscular effort from the steady series of seizures which might further elevate the temperature, a total of $65 \mathrm{cc}$. of venethane ether by inhalation was necessary. Unfortunately, plasma specific gravity measurements were not obtained before treatment, but a reading taken when the Evipal was given was 1.0175 , the lowest ever observed. The patient's temperature remained between $40.0^{\circ} \mathrm{C}$. and $41.0^{\circ} \mathrm{C}$. for the next 12 hours, in spite of efforts to reduce it. The skin was extremely dry, with no evidence of any sweating and there was no urinary output. Because of the extreme overhydration as indicated by the plasma specific gravity, the administration of fluid was withheld. One cc. of salyrgan and 0.4 gram of digitalis were given intravenously for their diuretic effect. Following this, and over the next 12-hour period, the patient excreted $1200 \mathrm{cc}$. of urine, and by the next afternoon, was on the way to recovery from the excessive fluid storage. The blood pressure during the 10 hours of actual treatment varied between $100 / 50$ and $115 / 30$. This patient was not outwardly 
edematous at any time, the overhydration apparently being mostly within the circulating system and brain. This situation may be very confusing to the clinician, for the appearance is all in favor of dehydration. Without the intervention of the anesthetics to stop the seizures, which if they had continued would have raised the body temperature still higher, and the effective application of diuretics to eliminate the excessive fluid, this case would undoubtedly have had a fatal termination.

\section{SEASONAL VARIATION}

It was noted that during January, February, and March of each year, the plasma specific gravity values were consistently higher than previously, and that individuals were encountered during these months who could not be "properly" hydrated prior to artificial fever therapy. It was during these months that Cases 7 and 8, discussed under the dehydrated group, were encountered. Representative averages for the last 4 years of normal cases and observations before and after fever treatment have been plotted in Figure 10. It may be seen that a definite change in the level is established during the late winter months. In

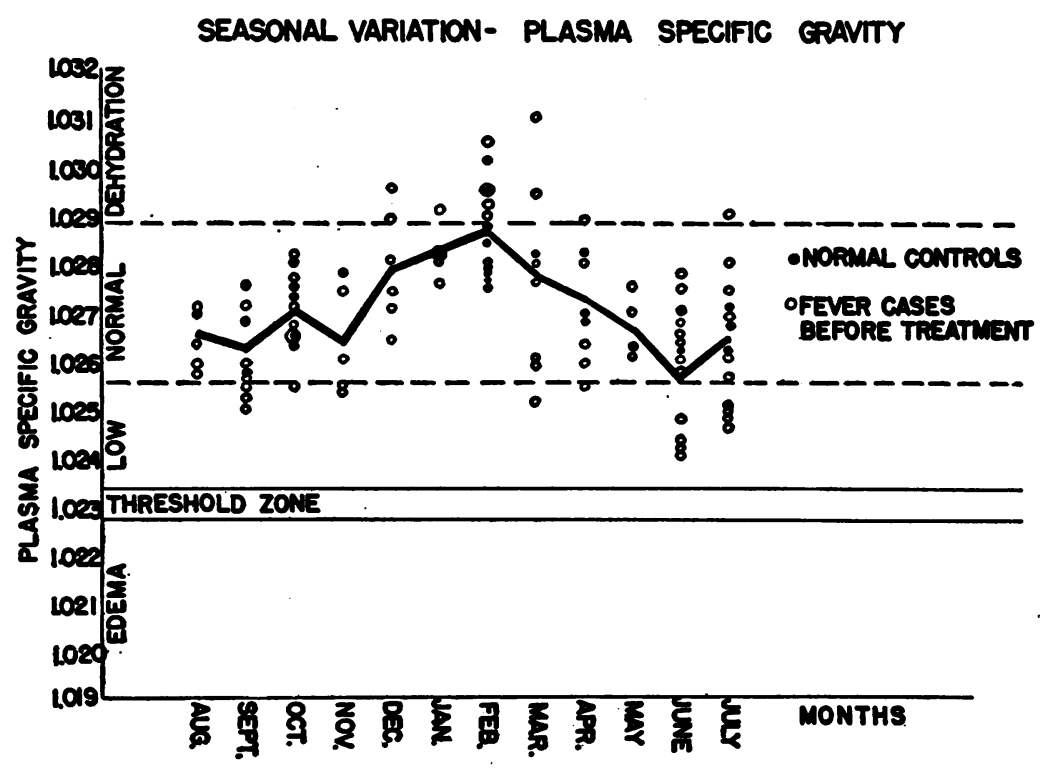

Fig. 10

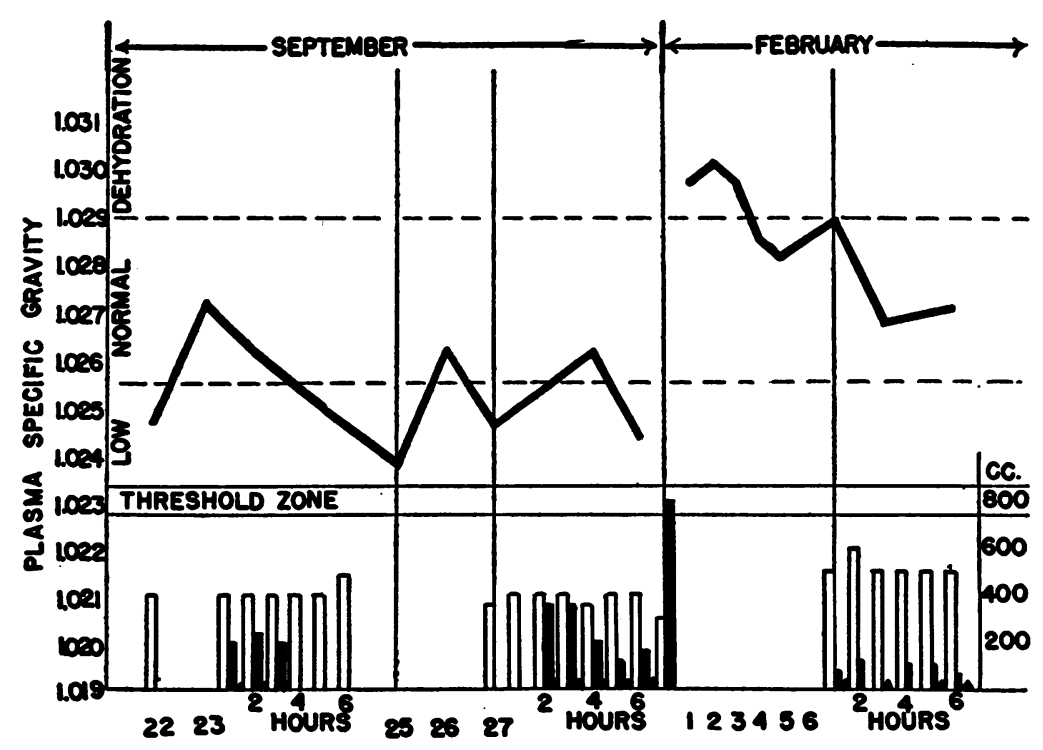

FIG. 11 
Case Number 11 (Figure 11), observed and treated in September and again in February, there is noted a decided shift of the plasma specific gravity levels. This illustrates an observation noted many times in the same individual receiving fever therapy in two different seasons of the year. Bazett et al. (34) has reported differences in blood volume in summer and winter. Barcroft et al. (4), by means of the carbon monoxide method of blood volume measurement, showed an average increase of 10 to 25 per cent in blood volume in subjects who travelled from England through the tropics. We conducted several preliminary experiments in which the room temperatures and humidity were elevated to "summer levels" for short periods of 3 to 5 days during the winter. The storage of water was less than 1 per cent and the changes were not in accordance with the magnitudes reported by Bazett (36). The significance of a seasonal variation in hydration is not well understood although it probably is related in some way to the dry cold part of our winter. However, if one is mindful that such a change can take place, certain dangers in fluid management can be eliminated.

\section{SUMMARY}

The incidence of collapse during artificial fever therapy can be greatly reduced by judicious replacement of water and sodium chloride lost in sweat.

The development of collapse is found to be associated with dehydration and, occasionally, overhydration of the blood plasma.

The symptoms accompanying both of these states resemble those of traumatic shock; pallor, cold extremities, and high body temperature, absence of sweating and urinary excretion, mania or unconsciousness.

There is therefore need for a guide to control the water and salt intake. This is satisfactorily provided by measurement of plasma specific gravity. This easily obtainable datum dependably forecasts the development of collapse and is therefore an extremely important item of procedure in artificial fever therapy.

The authors wish to express their appreciation to Drs. William S. McCann, Samuel Bassett, Henry Keutmann, and Harold $\mathrm{C}$. Hodge for their many suggestions regard- ing the treatment of our patients; to Dr. Nolan Kaltreider for his blood volume studies during the studies on seasonal variation; to Miss Emmy Lehman, fever nurse during the early years, Mr. Francis W. Bishop, for technical assistance, to two former fever residents, Dr. Gerald O'Hara and Dr. Harold Cohn,-all of whom contributed their part to the successful conduct of these experiments.

\section{BIBLIOGRAPHY}

1. Peters, J. P., Body Water. The Exchange of Fluids in Man. C. C. Thomas, Springfield, Ill., 1935.

2. Bazett, H. C., Physiological responses to heat. Phys. Rev., 1927, 7, 531.

3. Hargroves, M. H., and Doan, C. A., The physiological response of the hemopoetic tissues to artificially induced fever. Report of Fifth Ann. Fever Conf., May, 1935.

4. Barcroft, J., Meakins, J. C., Davies, H. W., Scott, J. M. D., and Fetter, W. J., On the relation of external temperature to blood volume. Phil. Trans. Royal Soc., London, 1923, 211, 455.

5. Barcroft, J., Binger, C. A., Bock, A. V., Doggert, J. H., Forbes, H. T., Harrop, G., Meakins, J. C., and Redfield, A. C., Observations upon the effect of high altitude on the physiological processes of the human body. Phil. Trans. Royal Soc., London, 1923, 211, 351.

6. Gibson, J. G., 2nd, and Evans, W. A., Jr., Clinical studies of the blood volume. Clinical application of a method employing the azo dye "Evans blue" and the spectrophotometer. J. Clin. Invest., 1937, 16, 301.

7. Evans, W. A., Jr., and Gibson, J. G., 2nd, Blood volume in diuresis. Am. J. Physiol., 1937, 118, 251.

8. Hemingway, A., Scott, F. H., and Wright, H. N., Kinetics of elimination of dye water blue from dog plasma after intravenous injection. Am. J. Physiol., 1935, 112, 56.

9. Chanutin, A., Smith, A. H., and Mendel, L. B., Factors concerned in blood volume regulation. Am. J. Physiol., 1924, 68, 444.

10. Gregersen, M. I., and Stewart, J. D., Simultaneous determination of the plasma volume with T-1824 and the "available fluid" volume with sodium thiocyanate. Am. J. Physiol., 1939, 125, 142.

11. Bale, W. F., Kaltreider, N. L., and White, W., Measurement of extracellular space with radioactive sodium. Unpublished data.

12. Gibson, J. G., 2nd, and Kopp, I., Studies in the physiology of artificial fever. Changes in the blood volume and water balance. J. Clin. Invest., 1938, 17, 219.

13. Gibson, J. G., 2nd, Kopp. I., and Pijoan, M., Acid-Base Balance During Therapeutic Fever. First Internat. Conf. on Fever, Paul B. Hoeber, Inc., New York, 1937.

14. Bierman, W., and Fishberg, E. H., Some physiologic changes during hyperpyrexia induced by physical means. J. A. M. A., 1934, 103, 1354. 
15. Goldfeder, A., Radiothermy on oxygen content and capacity in human blood. Arch. Phys. Therapy, 1933, 14, 339.

16. Dennie, C. C., Polsky, M., and Lemoine, A. N., Hyperpyrexia produced by the hot bath in the treatment of syphilis. J. Missouri M. A., 1936, 33, 1.

17. Krusen, F. H., The blood picture before and after fever therapy by physical means. Am. J. M. Sc., 1937, 193, 470.

18. Gross, W., and Kestner, O., Ueber die Einwirkung der Muskelarbeit und des Schwitzens auf Blut und Gewebe. Ztschr. f. Biol., 1919, 70, 187.

19. Cohn, E., Ueber die Veränderung des Hämoglobins sowie des Eiweissgehaltes im Blutserum bei Muskelarbeit und Schwitzen. Ztschr. f. Biol., 1919, 70. 366.

20. Simon, J. F., The effect of hyperpyrexia on the human blood count, blood chemistry, and urine. J. Lab. and Clin. Med., 1936, 21, 400.

21. Herrin, R. C., Chemical changes in blood and intestinal juice produced by the loss of intestinal juice. J. Biol. Chem., 1935, 108, 547.

22. Darrow, D. C., and Yannet, H., The changes in the distribution of body water accompanying increase and decrease in extracellular electrolyte. J. Clin. Invest., 1935, 14, 266.

23. Keutmann, E. H., Bassett, S. H., and Warren, S. L., Electrolyte balances during artificial fever. J. Clin. Invest., 1939, 18, 239.

24. Swingle, W. W., and Pfiffner, J. J., Studies on the adrenal cortex. Am. J. Physiol., 1931, 96, 153 and 164.

25. Personal communications with Doctors W. Hawkins, R. Knutti, W. Madden, N. Kaltreider, and G. Meneely of our staff.
26. McCann, W. S., Clinical significance of the plasma proteins. New York State J. Med., 1934, 34, 923.

27. Moon, V. H., Shock and Related Capillary Phenomena. Oxford University Press, New York, 1938.

28. Lavietes, P. H., D'Esopo, L. N., and Harrison, H. E., The water and base balance of the body. J. Clin. Invest., 1935, 14, 251.

29. Gamble, J. L., Extracellular fluid and its vicissitudes. Bull. Johns Hopkins Hosp., 1937, 61, 151.

30. Gamble, J. L., Dehydration. New England J. Med., 1929, 201, 909.

31. Brown, H. R., Jr., and Clark, W. F., Plasma specific gravity and control of fluid administration in artificial fever. Proc. Soc. Exper. Biol. and Med., 1939, 40, 490.

32. Moore, N. S., and Van Slyke, D. D., The relationships between plasma specific gravity, plasma protein content and edema in nephritis. J. Clin. Invest., 1930, 8, 337.

33. Peters, J. P., and Van Slyke, D. D., Quantitative Clinical Chemistry: Interpretations, p. 683. Williams and Wilkins Co., Baltimore, 1931 (Vol. I, Chap. $13,653-713)$.

34. Blalock, A., Principles of Surgical Care, Shock and Other Problems. C. V. Mosby, St. Louis, 1940.

35. Baird, M. M., and Haldane, J. B. S., Salt and water elimination in man. J. Physiol., 1922, 56, 259.

36. Bazett, H. C., Studies on the effects of baths on man. Am. J. Physiol., 1924, 70, 412.

37. Manery, J. F., and Bale, W. F., The penetration of radioactive sodium and phosphorus into the extraand intracellular phases of tissues. Am. J. Physiol., 1941, 132, 215. 